\title{
Visual Disturbance
}

National Cancer Institute

\section{Source}

National Cancer Institute. Visual Disturbance. NCI Thesaurus. Code C50805.

An interference to normal eyesight. 